\title{
Influence of Salinity on Duckweed Growth and Duckweed Based Wastewater Treatment System
}

\author{
Sena Peace Hounkpe Wendeou ${ }^{1}$, Martin Pepin Aina ${ }^{1}$, Martin Crapper², Edmond Adjovi ${ }^{1}$, \\ Daouda Mama ${ }^{3}$ \\ ${ }^{1}$ Civil Engineering Department, Université d'Abomey-Calavi, Cotonou, Benin \\ ${ }^{2}$ School of Engineering, The University of Edinburgh, Edinburgh, UK \\ ${ }^{3}$ Faculy of Science and Technology, Université d'Abomey-Calavi, Cotonou, Benin \\ Email: senapeace@yahoo.fr
}

Received August 10, 2013; revised September 11, 2013; accepted September 28, 2013

Copyright (C) 2013 Sena Peace Hounkpe Wendeou et al. This is an open access article distributed under the Creative Commons Attribution License, which permits unrestricted use, distribution, and reproduction in any medium, provided the original work is properly cited.

\begin{abstract}
The growth of duckweed (Spirodela polyrrhiza) was investigated in an outdoor batch system under 15 different conductivities ranging from $200 \mu \mathrm{S} / \mathrm{cm}$ to $3000 \mu \mathrm{S} / \mathrm{cm}$ with average $110 \mu \mathrm{mol} / \mathrm{m}^{2}$ daylight intensity. The growth was performed in an anaerobically treated domestic wastewater using an initial plants population of 50 fronds. Increase in Relative Growth Rate-RGR - (in terms of fresh weight and number of fronds) had a significant non-linear (polynomial) relationship with the conductivity. The maximum RGR related to fresh weight of 0.176 was observed at the conductiviity of $1200 \mu \mathrm{S} / \mathrm{cm}$ while the maximum RGR related to fronds number was 0.193 at the conductivity of $800 \mu \mathrm{S} / \mathrm{cm}$. The optimum range for duckweeds growth was found to be between conductivities of $600 \mu \mathrm{S} / \mathrm{cm}$ and $1400 \mu \mathrm{S} / \mathrm{cm}$. The maximal rates of removal of COD of $14.5 \mathrm{mg} /$ day, $\mathrm{PO}_{4}^{2-}$ of $0.65 \mathrm{mg} / \mathrm{day}$, NTK of $15.68 \mathrm{mg} /$ day, faecal coliforms of $100 \%$ and turbidity of $80.8 \%$ were observed in this range. The COD and $\mathrm{PO}_{4}^{2-}$ removal rates were highly correlated to the growth rate, with the correlation factor of up to 0.783 and, then to the conductivity. The NTK reduction was positively related to the conductivity.
\end{abstract}

Keywords: Duckweed; S. polyrrhiza; Growth Rate; Conductivity; Domestic Wastewater

\section{Introduction}

Duckweeds are the simplest smallest aquatic flowering plants [1]. They grow in colonies forming a green dense and uniform mat covering the surface of the water. They belong to the scientific family of monocotyledon floating plants Lemnaceae which consist of 4 genera: Lemna, Spirodela, Wolffia and Wolffiella and 28 species [1,2]. Their leaves and stems are not distinguishable like in other vascular plants; they are fused to form the so called "fronds" [3]. In adequate growth conditions (temperature, nutrient, light intensity, salinity), these plants can double their total fronds number and biomass every 2 to 4 days [3-6]. They are one of the plants with the most vigorous growth on the earth $[2,7]$.

The characteristics that make this plant grow rapidly in polluted waters make it an ideal candidate for large-scale application for nutrient removal and water purification. They are probably the best macrophyte to convert nutria- ent to biomass [3,8-10]. Duckweeds systems have been used to remove pollutants from varying qualities of domestic wastewater [3,6,11-14], septage [15], and agricultural wastewater such as swine water $[13,16]$. It has been reported that these plants help in the uptake of heavy metals from polluted waters as well as improve the overall quality of eutrophic water bodies [17-19]. Compared with most other aquatic plants, duckweeds have a greater potential and the overall low cost as treatment system because of their unique morphological and physiological properties, their high nutritional value and the diverse reuse opportunity they offer [2,7,13,20-22].

However, some studies' results suggest that the distribution of duckweeds is influenced by a number of factors, such as nutrients availability [23], pH [24], light intensity [6], temperature $[1,2,6,25]$, the dissolved oxygen content [26] and the salinity [13]. It has been reported that the growth rate of aquatic plants is inversely proportional to the increase in dissolved salt content of the wa- 
ter and their efficiency in water purification. A search of the literature for evidence concerning the effects of salinity on duckweeds has revealed little information. The present state of knowledge about the influence of salinity on duckweeds growth is summarized as duckweeds grow on a wide range of saline water and the observation of healthy duckweeds growth at a conductivity of 1460 $\mu \mathrm{S} / \mathrm{cm}[2]$. Apparently, no observations were recorded on wastewaters at different salinity and so one cannot judge on the natural tolerance limits for the duckweed.

The purpose of this research was to investigate the effect of wastewater dissolved salt content on the growth of duckweeds (Spirodela) when a duckweed system is employed for municipal wastewater treatment. Also, the effect of plant growth on the removal efficiencies of certain pollutants was investigated.

\section{Materials and Methods}

\subsection{Plant Material and Culture Medium}

The duckweeds (Spirodela) clones used were collected on the lake Nokoue located in southern Benin (West Africa). They have been grown for several months in wastewater treatment ponds on the University Campus of Abomey-Calavi (Benin). Fifty clones of healthy plants were selected from the ponds and were introduced directly into the culture medium without a further acclimatisation. The culture medium was domestic wastewater anaerobically treated in an anaerobic waste stabilisation pond.

The behaviour of duckweeds during an experiment depends on its previous immediate history which may affect results [27]. To avoid systematic errors related to the use of population of different history, the experiments were carried out simultaneously in parallel under the same conditions with plants from the same point.

\subsection{Experimental Design}

Plastics containers of $16 \mathrm{~cm}$ of mean diameter, $14 \mathrm{~cm}$ of height were filled with $1500 \mathrm{~mL}$ of domestic wastewater which had received an anaerobic treatment and had its conductivity adjusted. The containers were placed outdoor under natural conditions. The initial conductivity of the pre-treated wastewater was $712 \mu \mathrm{S} / \mathrm{cm}$. Fifteen containers have been used with the conductivity varying from $200 \mu \mathrm{S} / \mathrm{cm}$ to $3000 \mu \mathrm{S} / \mathrm{cm}$, that is, salinity from 154 $\mathrm{mg} / \mathrm{L}$ to $2276 \mathrm{mg} / \mathrm{L}$. To obtain the conductivity of 200 $\mu \mathrm{S} / \mathrm{cm}$ to $600 \mu \mathrm{S} / \mathrm{cm}$ (below the initial conductivity), the pre-treated domestic wastewater was diluted with distilled water. The conductivities from $800 \mu \mathrm{S} / \mathrm{cm}$ to 3000 $\mu \mathrm{S} / \mathrm{cm}$ have been adjusted by adding $\mathrm{NaCl}$ to the pretreated wastewater. The cultures were started with 50 fronds of duckweeds. The total experimental period was 10 days. The plants initially covered $25 \%$ of the surface of the water in the containers. This initial density was used to prevent very dense coverage and excess overlaps of fronds of duckweeds during the experiment, which could affect plants growth [2]. The number of fronds was counted at the beginning and the end of the experiments. The total mass of plants was also measured at the beginning and the end of the experiments. The pre-treated domestic wastewater used was not replaced during the whole period of experimentation.

\subsection{Techniques of Measurement and Analysis}

The growth rates were measured by counting separately the number of fronds and weighing the wet biomass at the beginning and the end of the experimental period. The wet mass was measured by removing the excess water by placing and rolling the plants cautiously between absorbent paper tissues and by weighing the biomass immediately after that. Knowing the biomass weight, the plants relative growth rate (RGR) is calculated by Equation (1) below [12,24]:

$$
\mathrm{RGR}=\left[\ln \left(m_{f} / m_{i}\right)\right] / t
$$

where, $\mathrm{m}_{\mathrm{i}}$ and $\mathrm{m}_{\mathrm{f}}$ are respectively the initial and the final wet weight (or number of fronds) at the start and the end of the experimental period and $t$ is the number of days between 2 weighing or counting.

The biomass doubling time can be calculated by Equation (2):

$$
\text { Doubling Time }=[\ln (2)] / \mathrm{RGR}
$$

To estimate the treatment performance of the duckweeds under different salinities, some parameters were measured. The environmental parameters such as the $\mathrm{pH}$, the temperature, the conductivity, the dissolved oxygen, the light intensity and the Total Dissolved Solids (TDS) were measured on daily basis. The chemical oxygen demand (COD), the suspended solids, the Nitrogen Total Kjeldhal (NTK), the phosphate and the faecal coliforms were determined at the beginning and the end of the experimental period.

The $\mathrm{pH}$, temperature, conductivity, light intensity and dissolved oxygen were measured on site. The $\mathrm{pH}$ and temperature were measured with the $\mathrm{pH}$-meter $\mathrm{pH} 3110$ SET 3 (WTW) of \pm 0.01 upH of accuracy in accordance with the standard NF T 90-008.

The electrical conductivity, in $\mu \mathrm{S} / \mathrm{cm}$ (micro-Siemens per centimetre), was measured with a conductivity-meter $\mathrm{pH} / \mathrm{EC} / \mathrm{TDS}$ Waterproof Family in accordance with the standard NF EN 27888 class index T 90-031. The salinity was deducted from the measured conductivity in accordance with the standard NF T 90-111 using the Equation (2) [28].

$$
\text { Salinity }\left(\text { in } \frac{m g}{L}\right)=K * \text { conductivity }(\mu \mathrm{S} / \mathrm{cm})
$$


$K$ is a constant depending on the conductivity.

The dissolved oxygen was measured with the oxymeterOxi 730 in accordance with NF T 90-106 standard. The CODand the NTK were measured based on the NF T 90-101 and NF T 90-110, respectively. The concentration of phosphate was determined by molecular adsorption using the spectrophotometer DR 2800. The counting of faecal coliforms in the water was done in accordance the standard NF T-90416.

The relation between the salinity, growth rate and removal performances of the duckweed was studied by means of statistical analysis using the principal component analysis (PCA) by correlation matrix.

\section{Results and Discussion}

\subsection{Environmental Conditions}

The observed environmental conditions during the experimental period were quite adequate for a good growth of the duckweeds.

The minimum temperatures of water in the containers varied from $25.4^{\circ} \mathrm{C}$ to $25.6^{\circ} \mathrm{C}$ and the maximum temperatures varied from $27.3^{\circ} \mathrm{C}$ to $27.7^{\circ} \mathrm{C}$, with an overall range of average temperatures of water of $26.4^{\circ} \mathrm{C} \pm 0.8^{\circ} \mathrm{C}$ to $26.7^{\circ} \mathrm{C} \pm 0.7^{\circ} \mathrm{C}$. The average water temperatures showed reasonably low variations and always stayed within the reported optimum range of duckweeds growth, $20^{\circ} \mathrm{C}$ to $30^{\circ} \mathrm{C}[1,25]$.

The minimum and maximum $\mathrm{pH}$ values varied from 6.47 to 7.15 and 9.04 to 9.69 , respectively. The average $\mathrm{pH}$ values, varying from $7.5 \pm 0.8$ to $8.1 \pm 0.9$, fell within the reported optimum $\mathrm{pH}$ values range of duckweeds growth [24]. After 3 days of experiment, a presence of algae in the containers was noticed. An increase of $\mathrm{pH}$ was observed from the beginning of the experiment to reach its higher value in the range of the maximum values of $\mathrm{pH}$ registered (Figure 1). After then, the $\mathrm{pH}$ dropped back to normal level, around 7, very rapidly. This change of water $\mathrm{pH}$ during the experiment was directly associated with the growth of phototrophic algae which could result in the depletion
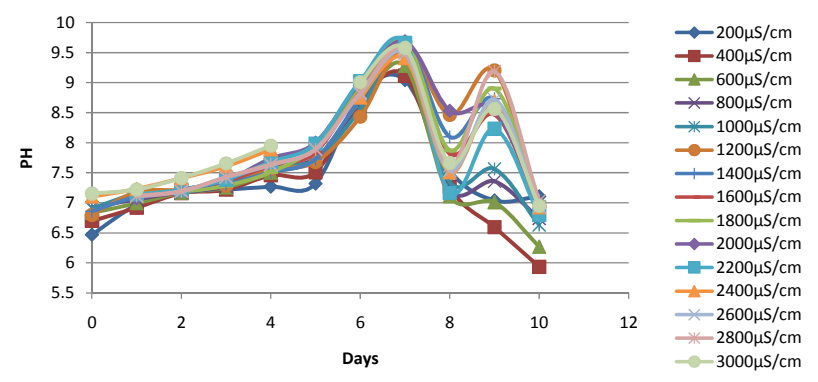

Figure 1. Changes of pH of the duckweed ponds at different water conductivities during the experimental period. of carbon dioxide in water and, consequently, a high water $\mathrm{pH}$. The drop in the $\mathrm{pH}$ value was due to the increase of duckweed coverage density to a value close to $100 \%$ which led to the depletion or disappearance of the algae biomass.

The daylight intensity recorded during the experimental period varied between a minimum value of 56 $\mu \mathrm{mol} / \mathrm{m}^{2}$ and a maximum value of $396 \mu \mathrm{mol} / \mathrm{m}^{2}$, with an average daily value of $110 \mu \mathrm{mol} / \mathrm{m}^{2}$. A relatively good growth rate of duckweeds has been reported at this range of light intensity [12]. The average daily value was smaller than $300 \mu \mathrm{mol} / \mathrm{m}^{2}$, the reported light intensity saturation value for duckweeds $[29,30]$.

The conductivities and TDS were stable at the beginning of the experiment in the containers. A rapid increase of the conductivity and the TDS was observed in all the containers during the experimental periods between the sixth and seventh days when the $\mathrm{pH}$ started dropping down, and slowed than after the seventh day (Figures 2 and 3). This increase in conductivity was associated with the evapotranspiration phenomenon related to the increase of plant biomass in the ponds.

\subsection{Visual Observation}

The three containers with wastewater at conductivities of 800,1200 and $1400 \mu \mathrm{S} / \mathrm{cm}$ showed very green healthy plants with new fronds size visibly bigger than the initial fronds size. There was a full water surface coverage by the plants in those containers. A reduction in plants size was observed in the containers with conductivity from

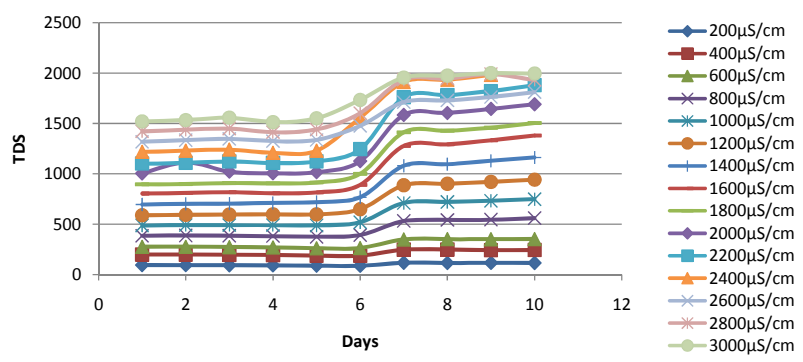

Figure 2. Changes in TDS of the duckweed ponds during the experimental period.

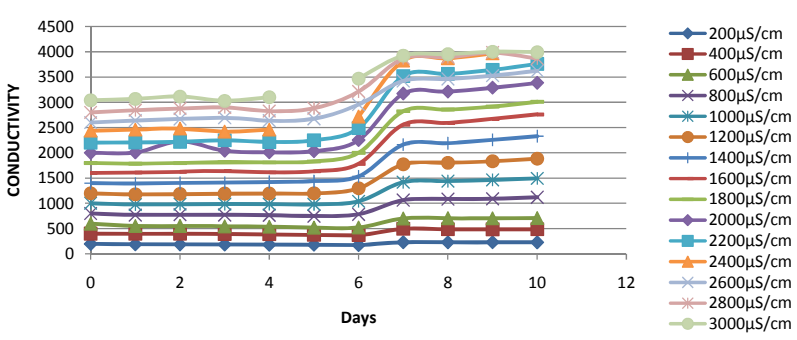

Figure 3. Changes in conductivity of the duckweed ponds during the experimental period. 
600 to $200 \mu \mathrm{S} / \mathrm{cm}$ and from 1600 to $3000 \mu \mathrm{S} / \mathrm{cm}$. This reduction of plants size from 1600 to $3000 \mu \mathrm{S} / \mathrm{cm}$ was followed by a change in the fronds colour to green-yellowish green from the conductivity of $1800 \mu \mathrm{S} / \mathrm{cm}$. The smallest fronds sizes were observed with conductivity of 2600, 2800 and $3000 \mu \mathrm{S} / \mathrm{cm}$.

\subsection{Effect of Salinity on the Growth Rate}

The relative growth rate increased from $0.141 /$ day at a conductivity of $200 \mu \mathrm{S} / \mathrm{cm}$ to a maximum value of 0.176 /day at a conductivity of $1200 \mu \mathrm{S} / \mathrm{cm}$. As the conductiveity increased above $1200 \mu \mathrm{S} / \mathrm{cm}$, the relative growth started to decline and reached the minimum value of 0.81 /day at conductivity of $2800 \mu \mathrm{S} / \mathrm{cm}$ (Figure 4). These represented a biomass doubling time varying from 3.9 days to 8.5 days. After 10 days, when the experiments were terminated, an average maximum increase in plant mass of $4.82 \mathrm{~g}$, about five times the initial value was observed, when the conductivity was $1200 \mu \mathrm{S} / \mathrm{cm}$. The greatest and smallest unit fronds masses of $0.021 \mathrm{~g} /$ frond with a leave size up to $9 \mathrm{~mm}$ and $0.015 \mathrm{~g} /$ frond with leave size less than $6 \mathrm{~mm}$ were obtained at the conductivities of $1000 \mu \mathrm{S} / \mathrm{cm}$ and $2800 \mu \mathrm{S} / \mathrm{cm}$, respectively. This confirmed the visual observation.

It was observed that the relative growth rate based on fronds number is greater or smaller than that based on the wet weight depending on the conductivity with a different trend. This was due to the fact that the fronds sizes, and consequently their unit masses, were not identical at all conductivities.

The salinity was the controlling factor for duckweed growth. The growth rate of duckweeds as a function of the conductivity, after fitting, followed a polynomial pattern with the optimum at the conductivity of 1200 $\mu \mathrm{S} / \mathrm{cm}$. The correlation factor $\mathrm{R}^{2}$ was 0.903 for the wet weight RGR and 0.7003 for fronds count RGR (Figures 4 and 5). As a conclusion, it appears better to use the RGR related to wet weight when predicting growth as function of salinity.

The conductivity from $2000 \mu \mathrm{S} / \mathrm{cm}$ to $3000 \mu \mathrm{S} / \mathrm{cm}$ reflected conditions with conductivity being a growth limi-

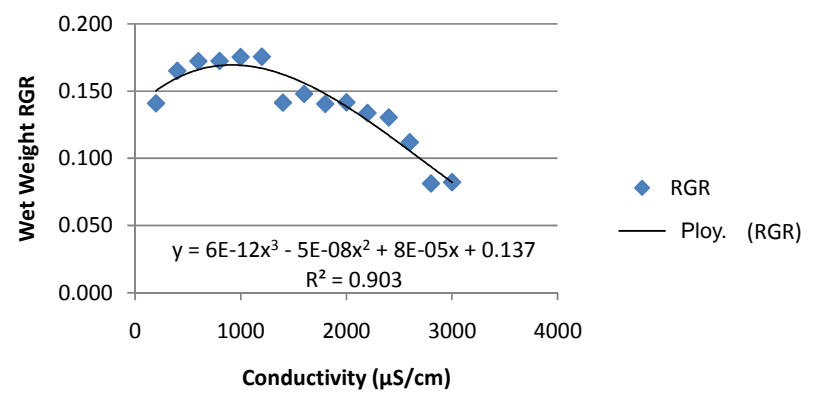

Figure 4. Duckweeds wet weight relative growth rate (RGR) as function of conductivity. ting factors. Applying conductivity different from the optimum conductivity of $1200 \mu \mathrm{S} / \mathrm{cm}$ increased the biomass doubling time. The optimum conductivity is found to be $1200 \mu \mathrm{S} / \mathrm{cm}$ with the favourable range between 600 and $1400 \mu \mathrm{S} / \mathrm{cm}$.

\subsection{Duckweeds Ponds Performances}

The initial composition of the anaerobically treated waste water used was shown in Table 1. The water in the containers of conductivities 200, 400 and $600 \mu \mathrm{S} / \mathrm{cm}$ was diluted with the dilution coefficients equal to $3.73,1.79$, and 1.20 , respectively.

The increase in biomass of duckweeds is followed by a removal of pollutants from the wastewater. The removal efficiencies of certain parameters in the wastewater as affected by the plant growth were investigated. Table 2 shows the removal efficiency of certain selected pollutants present in the wastewater.

The reduction of the turbidity of the water ranged between $56.7 \%$ and $80.8 \%$ (Table 2). The turbidity seemed to be in a weak positive correlation with the COD, the phosphate and faecal coliforms. No direct relation between the reduction in turbidity and the plants growth or conductivity was observed (Table 3 ). This indicated the level of removal of suspended solids from the water. It

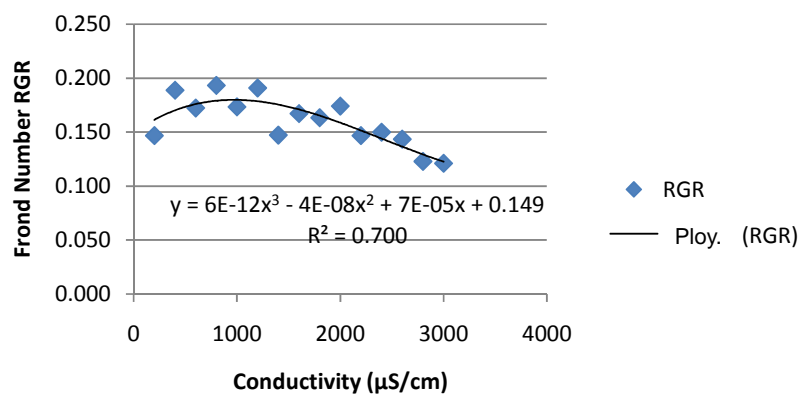

Figure 5. Duckweeds frond number relative growth rate (RGR) as function of conductivity.

Table 1. Initial characteristics of the anaerobically treated domestic wastewater.

\begin{tabular}{ccc}
\hline Parameters & Units & Value \\
\hline $\mathrm{pH}$ & ${ }^{\circ} \mathrm{C}$ & 6.9 \\
Temperature & $\mu \mathrm{S} / \mathrm{cm}$ & 25.7 \\
Conductivity & $\mathrm{mg} \mathrm{O} / \mathrm{L}$ & 712 \\
COD & $\mathrm{mg} / \mathrm{L}$ & 175.4 \\
Phosphate & $\mathrm{mg} / \mathrm{L}$ & 13.60 \\
NTK & number/100 mL & 15.68 \\
Faecal Coliform & $\mathrm{NTU}$ & $3.6 \times 10^{4}$ \\
Turbidity & & 6.17 \\
\hline
\end{tabular}


Table 2. Certain pollutants removal efficiency of the duckweeds based ponds at different conductivities.

\begin{tabular}{|c|c|c|c|c|c|c|c|c|c|c|}
\hline \multirow{2}{*}{$\begin{array}{c}\text { Conductivit } \\
\mathrm{y}(\mu \mathrm{S} / \mathrm{cm})\end{array}$} & \multicolumn{2}{|c|}{ Plant growth } & \multicolumn{2}{|c|}{ COD removal } & \multicolumn{2}{|c|}{ Phosphate removal } & \multicolumn{2}{|c|}{ NTK removal } & \multirow{2}{*}{$\begin{array}{l}\text { Feacalcoliforms } \\
\text { removal }\end{array}$} & \multirow{2}{*}{$\begin{array}{l}\text { Turbidity } \\
\text { removal }\end{array}$} \\
\hline & M formed g/day & RGR $\left(\right.$ Day $\left.^{-1}\right)$ & $\mathrm{mg} / \mathrm{m}^{2} \cdot$ day & $\%$ & $\mathrm{mg} / \mathrm{m}^{2} \cdot$ day & $\%$ & $\mathrm{mg} / \mathrm{m}^{2} \cdot$ day & $\%$ & & \\
\hline 200 & 2.92 & 0.141 & 84.67 & $36.2 \%$ & 12.66 & $69.8 \%$ & 9.73 & $100.0 \%$ & $83.5 \%$ & $74.8 \%$ \\
\hline 400 & 4.10 & 0.165 & 338.15 & $69.4 \%$ & 28.79 & $76.2 \%$ & 5.67 & $15.6 \%$ & $100.0 \%$ & $70.5 \%$ \\
\hline 600 & 4.74 & 0.172 & 577.77 & $79.5 \%$ & 30.26 & $53.7 \%$ & 64.99 & $100.0 \%$ & $99.7 \%$ & $72.4 \%$ \\
\hline 800 & 4.69 & 0.172 & 723.08 & $82.9 \%$ & 29.59 & $43.8 \%$ & 77.99 & $100.0 \%$ & $98.9 \%$ & $72.8 \%$ \\
\hline 1000 & 4.82 & 0.175 & 642.74 & $73.7 \%$ & 31.58 & $46.7 \%$ & 77.99 & $100.0 \%$ & $100.0 \%$ & $80.8 \%$ \\
\hline 1200 & 4.48 & 0.176 & 413.19 & $47.4 \%$ & 32.33 & $47.8 \%$ & 77.99 & $100.0 \%$ & $99.9 \%$ & $62.2 \%$ \\
\hline 1400 & 3.14 & 0.141 & 413.19 & $47.4 \%$ & 25.37 & $37.5 \%$ & 69.63 & $89.3 \%$ & $100.0 \%$ & $66.0 \%$ \\
\hline 1800 & 3.44 & 0.140 & 275.46 & $31.6 \%$ & 22.38 & $33.1 \%$ & 77.99 & $100.0 \%$ & $76.4 \%$ & $57.1 \%$ \\
\hline 2000 & 3.42 & 0.142 & 229.55 & $26.3 \%$ & 29.84 & $44.1 \%$ & 77.99 & $100.0 \%$ & $99.9 \%$ & $56.7 \%$ \\
\hline 2200 & 2.56 & 0.134 & 91.82 & $10.5 \%$ & 26.86 & $39.7 \%$ & 75.20 & $96.4 \%$ & $100.0 \%$ & $78.7 \%$ \\
\hline 2400 & 2.85 & 0.130 & 229.55 & $26.3 \%$ & 25.37 & $37.5 \%$ & 75.20 & $96.4 \%$ & $100.0 \%$ & $63.8 \%$ \\
\hline 2600 & 2.36 & 0.112 & 137.73 & $15.8 \%$ & 23.38 & $34.6 \%$ & 77.99 & $100.0 \%$ & $100.0 \%$ & $63.1 \%$ \\
\hline 2800 & 1.38 & 0.081 & 229.55 & $26.3 \%$ & 15.42 & $22.8 \%$ & 77.99 & $100.0 \%$ & $100.0 \%$ & $64.2 \%$ \\
\hline 3000 & 1.50 & 0.082 & 137.73 & $15.8 \%$ & 17.90 & $26.5 \%$ & 77.99 & $100.0 \%$ & $99.8 \%$ & $76.6 \%$ \\
\hline
\end{tabular}

Table 3. Correlation matrices inter-parameters.

\begin{tabular}{|c|c|c|c|c|c|c|c|c|c|c|}
\hline Variables & Conductivity & $\begin{array}{c}\text { Wet Weight } \\
\text { RGR }\end{array}$ & $\begin{array}{c}\mathrm{PO}_{4}^{-} \\
\text {removal in } \\
\mathrm{mg} / \text { day }\end{array}$ & $\begin{array}{c}\text { NTK } \\
\text { removal in } \\
\text { mg/day }\end{array}$ & $\begin{array}{c}\mathrm{COD} \\
\text { removal in } \\
\mathrm{mg} / \mathrm{day}\end{array}$ & $\begin{array}{c}\text { COD } \\
\text { removal in } \\
\%\end{array}$ & $\begin{array}{c}\mathrm{PO}_{4}^{-} \\
\text {removal in } \\
\%\end{array}$ & $\begin{array}{l}\text { NTK } \\
\text { removal } \\
\text { in } \%\end{array}$ & $\begin{array}{c}\mathrm{FC} \\
\text { removal } \\
\text { in } \%\end{array}$ & $\begin{array}{c}\text { Turbidity } \\
\text { removal } \\
\text { in } \%\end{array}$ \\
\hline Conductivity & 1.000 & & & & & & & & & \\
\hline Wet Weight RGR & -0.826 & 1.000 & & & & & & & & \\
\hline $\mathrm{PO}_{4}^{3-}$ removal in mg/day & -0.305 & 0.745 & 1.000 & & & & & & & \\
\hline NTK removal in mg/day & 0.634 & -0.205 & 0.278 & 1.000 & & & & & & \\
\hline COD removal in $\mathrm{mg} /$ day & -0.529 & 0.706 & 0.654 & 0.192 & 1.000 & & & & & \\
\hline COD removal in $\%$ & -0.790 & 0.783 & 0.534 & -0.233 & 0.905 & 1.000 & & & & \\
\hline $\mathrm{PO}_{4}^{-}$removal in $\%$ & -0.864 & 0.649 & 0.221 & -0.845 & 0.164 & 0.526 & 1.000 & & & \\
\hline FC removal in $\%$ & 0.216 & -0.009 & 0.459 & 0.272 & 0.241 & 0.127 & -0.117 & -0.132 & 1.000 & \\
\hline Turbidity removal in \% & -0.267 & 0.100 & -0.114 & -0.271 & 0.138 & 0.252 & 0.232 & -0.096 & 0.163 & 1.000 \\
\hline
\end{tabular}

can be observed from this table that the higher the plant relative growth, the higher the removal efficiency of the chemical oxygen demand and the phosphate. In the first three containers of conductivities of 200, 400 and $600 \mu \mathrm{S} / \mathrm{cm}$, due to the dilution of the wastewater, meaning low initial value of pollutants concentrations, the removal rate of the pollutant (in percentage) appears high even though the mass of pollutant removed per day is smaller. For example, the masses of phosphate removed were $28.79 \mathrm{mg} / \mathrm{m}^{2}$ day and $32.33 \mathrm{mg} / \mathrm{m}^{2}$ day at conductivities of $400 \mu \mathrm{S} / \mathrm{cm}$ and $1200 \mu \mathrm{S} / \mathrm{cm}$, respectively, while the removal rates expressed in percentage were $76.28 \%$ and $47.79 \%$, respectively. Then, when the initial concentrations in pollutant in different ponds are not the 
same, it is better to compare the efficiency using the amount of the pollutant removed rather than the percentage of pollutant removed. The highest level of COD reduction was from $1754 \mathrm{mg} / \mathrm{L}$ to less than $30 \mathrm{mg} / \mathrm{L}$ with a removal rate greater than $723.1 \mathrm{mg} / \mathrm{m}^{2}$.day or $82.9 \%$. A similar reduction rate was observed in some previous studies [12]. This removal rate was observed at the conductivity of $800 \mu \mathrm{S} / \mathrm{cm}$ where the wet weight RGR was $0.172 /$ day. As for the phosphate, the maximum removal rate of $32.33 \mathrm{mg} / \mathrm{m}^{2}$. day was obtained at a conductivity of $1200 \mu \mathrm{S} / \mathrm{cm}$ and the wet weight RGR was 0.176 /day (Table 2). Apart from the plant growth, the conductivity affected the COD removal; the COD reduction was better at lower conductivity than at higher conductivity.

The COD and the phosphate removal rates were in significant positive correlation with the RGR and the biomass production (Table 3 ). This table showed that the COD and the phosphate contributed directly to the increase of plant biomass.

It has been observed a strong correlation related to the conductivity, inversely proportional to the plant relative growth rate; this result was showing that the conductivity, and then the salinity, was a limited factor for plants growth. This plants development was controlled, as shown by the correlation matrix, by the $\mathrm{PO}_{4}^{-}$and COD removal rates.

The reduction of faecal coliforms and NTK of $100 \%$ was achieved in most of the containers (Table 2).

Due to this complete removal of NTK and faecal coliforms, it was not possible to identify the real correlation between the reduction of these parameters and the plants growth. The correlation coefficients obtained were positive but not really significant (Table 3).

Average masses of $0.61 \mathrm{~g}$ and $1.3 \mathrm{~g}$ of plant biomass were formed per $1 \mathrm{mg}$ of phosphate and $1 \mathrm{mg}$ of NTK removed respectively.

\section{Conclusion}

For an optimum use of duckweed for wastewater treatment, the conductivity of the water should preferably be between 600 and $1400 \mu \mathrm{S} / \mathrm{cm}$. At this range of conductivities the wet weight relative growth rate reached its maximal value of $0.176 /$ day. Out of this range, the growth rate of the plants and therefore the removal performances declined. The maximum rates of removal of COD of $723.1 \mathrm{mg} / \mathrm{m}^{2}$ day, $\mathrm{PO}_{4}^{-}$of $32.33 \mathrm{mg} / \mathrm{m}^{2} \cdot$ day, NTK of $77.99 \mathrm{mg} / \mathrm{m}^{2} \cdot$ day, faecal coliforms of $100 \%$ and turbidity of $80.8 \%$ were observed in this range. This is because the rate of removal of phosphate and COD had a significant positive correlation with the duckweed growth rate. Conductivity (greater than $2000 \mu \mathrm{S} / \mathrm{cm}$ ), and corresponding salinity (greater than $1517 \mathrm{mg} / \mathrm{L}$ ), inhibited plant growth.

\section{Acknowledgements}

This paper reports results from a research work carried out with the financial support of Islamic Development Bank and the technical support of the Laboratory of Water Science and Technology of the University of Abomey-Calavi (Benin).

\section{REFERENCES}

[1] W. S. Hillman, "The Lemnaceae, or Duckweeds," The Botanical Review, Vol. 27, No. 2, 1961, pp. 221-287. http://dx.doi.org/10.1007/BF02860083

[2] L. Bonomo, G. Pastorelli and N. Zambon, "Advantages and Limitations of Duckweed-Based Wastewater Treatment Systems," Water Science and Technology, Vol. 35, No. 5, 1997, pp. 239-246. http://dx.doi.org/10.1016/S0273-1223(97)00074-7

[3] J. R. Caicedo Bejarano, "Effect of Operational Variables on Nitrogen Transformations in Duckweed Stabilization Ponds," Ph.D. Thesis, The UNESCO-IHE Institute for Water Education, Delft, 2005.

[4] E. Landolt and R. Kandeler, "The Family of Lemnaceae-A Monographic Study: Phytochemistry, Physiology, Application, and Bibliography. (Vol. 2 of Monograph)," Geobotanical Institute of the ETH, Stiftung Rubel, 1987.

[5] E. Landolt, "The Family of Lemnaceae-A Monographic Study: Vol 1: Morphology, Karyology, Ecology, Geographic Distribution, Systematic Position, Nomenclature, Descriptions," Veröffentlichungen des Geobotanischen Institutes der ETH, Stiftung Rubel, Zurich, 1986, p. 566.

[6] R. M. Harvey and J. L. Fox, "Nutrient Removal Using Lemna Minor," Water Pollution Control Federation, Vol. 45, No. 9, 1973, pp. 1928-1938.

[7] J. Xu, et al., "Production of High-Starch Duckweed and Its Conversion to Bioethanol," Biosystems Engineering, Vol. 110, No. 2, 2011, pp. 67-72. http://dx.doi.org/10.1016/j.biosystemseng.2011.06.007

[8] B. Ingemarsson, et al., "Nitrogen Utilization in Lemna II. Studies of Nitrate Uptake Using ${ }^{13} \mathrm{NO}_{3}^{-}$," Plant Physiology, Vol. 85, No. 3, 1987, pp. 860-864. http://dx.doi.org/10.1104/pp.85.3.860

[9] F. A. Nasr, H. S. Doma and H. F. Nassar, "Treatment of Domestic Wastewater Using an Anaerobic Baffled Reactor Followed by a Duckweed Pond for Agricultural Purposes," The Environmentalist, Vol. 29, No. 3, 2008, pp. 270-279. http://dx.doi.org/10.1007/s10669-008-9188-y

[10] D. Patel and V. Kanungo, "Phytoremediation Potential of Duckweed (Lemnaminor L: A Tiny Aquatic Plant) in the Removal of Pollutants from Domestic Wastewater with Special Reference to Nutrients," Bioscan, Vol. 5, No. 3, 2010, pp. 355-358.

[11] E. Awuah, "Pathogen Removal Mechanisms in Macrophyte and Algal Waste Stabilization Ponds," Taylor \& Francis, Leiden, 2006.

[12] F. A. Al-Nozaily, "Performance and Process Analysis of 
Duckweed-Covered Sewage Lagoons for High Strength Sewage: The Case of Sana'a, Yemen,” 2001.

[13] J. Xu, J. J. Cheng and A.-M. Stomp, "Growing Spirodela polyrrhiza in Swine Wastewater for the Production of Animal Feed and Fuel Ethanol: A Pilot Study," CLEANSoil, Air, Water, Vol. 40, No. 7, 2012, pp. 760-765. http://dx.doi.org/10.1002/clen.201100108

[14] S. Sengupta, C. Medda and A. Dewanji, "The Impact of Duckweed Growth on Water Quality in Sub-Tropical Ponds," The Environmentalist, Vol. 30, No. 4, 2010, pp. 353-360. http://dx.doi.org/10.1007/s10669-010-9293-6

[15] F. H. Papadopoulos and V. A. Tsihrintzis, "Assessment of a Full-Scale Duckweed Pond System for Septage Treatment," Environmental Technology, Vol. 32, No. 7, 2011, pp. 795-804. http://dx.doi.org/10.1080/09593330.2010.514009

[16] J. Cheng, et al., "Nutrient Removal from Swine Lagoon Liquid by Lemna Minor 8627," Transactions of the American Society of Agricultural Engineers, Vol. 45, No. 4, 2002, pp. 1003-1010.

[17] R. P. Staves and R. M. Knaus, "Chromium Removal from Water by 3 Species of Duckweeds," Aquatic Botany, Vol. 23, No. 3, 1985, pp. 261-273. http://dx.doi.org/10.1016/0304-3770(85)90070-1

[18] C. B. Sekomo, et al., "Heavy Metal Removal in Duckweed and Algae Ponds as a Polishing Step for Textile Wastewater Treatment," Ecological Engineering, Vol. 44, 2012, pp. 102-110. http://dx.doi.org/10.1016/j.ecoleng.2012.03.003

[19] A. Sasmaz and E. Obek, "The Accumulation of Arsenic, Uranium, and Boron in Lemna gibba L. Exposed to Secondary Effluents," Ecological Engineering, Vol. 35, No. 10, 2009, pp. 1564-1567. http://dx.doi.org/10.1016/j.ecoleng.2009.06.007

[20] P. Skillicorn, W. Spira and W. Journey, "Duckweed Aquaculture: A New Aquatic Farming System for Developing Countries," Banco Mundial, Washington DC, 1993.

[21] P. van der Steen, A. Brenner and G. Oron, "An Integrated Duckweed and Algae Pond System for Nitrogen Removal and Renovation," Water science and Technology, Vol. 38,
No. 1, 1998, pp. 335-343. http://dx.doi.org/10.1016/S0273-1223(98)00419-3

[22] G. Oron, D. Porath and L. R. Wildschut, "Wastewater Treatment and Renovation by Different Duckweed Species," Journal of Environmental Engineering, Vol. 112, No. 2, 1986, pp. 247-263.

http://dx.doi.org/10.1061/(ASCE)0733-9372(1986)112:2( 247)

[23] K. R. Reddy and W. F. Debusk, "Growth-Characteristics of Aquatic Macrophytes Cultured in Nutrient-Enriched Water. 1. Water Hyacinth, Water Lettuce, and Pennywort," Economic Botany, Vol. 38, No. 2, 1984, pp. 229239. http://dx.doi.org/10.1007/BF02858838

[24] C. McLay, "The Effect of $\mathrm{pH}$ on the Population Growth of Three Species of Duckweed: Spirodela Oligorrhiza, Lemna Minor and Wolffia Arrhiza," Freshwater Biology, Vol. 6, No. 2, 1976, pp. 125-136. http://dx.doi.org/10.1111/j.1365-2427.1976.tb01596.x

[25] R. M. Wedge and J. E. Burris, "Effects of Light and Temperature on Duckweed Photosynthesis," Aquatic Botany, Vol. 13, 1982, pp. 133-140. http://dx.doi.org/10.1016/0304-3770(82)90047-X

[26] H. Brix, "Do Macrophytes Play a Role in Constructed Treatment Wetlands?" Water Science and Technology, Vol. 35, No. 5, 1997, pp. 11-18. http://dx.doi.org/10.1016/0304-3770(82)90047-X

[27] E. Ashby and T. Oxley, "The Interaction of Factors in the Growth of Lemna VI. An Analysis of the Influence of Light Intensity and Temperature on the Assimilation Rate and the Rate of Frond Multiplication," Annals of Botany, Vol. 49, No. 2, 1935, pp. 309-336.

[28] O. Thomas, "Métrologie des eaux Résiduaires," CEBEDOC, Liège, 1995.

[29] H. White, "The Interaction of Factors in the Growth of Lemna. IX. Further Observations on the Effect of Light Intensity on Growth and Multiplication," Annals of Botany, Vol. 50, No. 4, 1936, pp. 827-848.

[30] M. L. Boss, M. J. Dijkman and V. B. Theiling, "Aging Studies on Lemna," Quarterly Journal of the Florida Academy of Sciences, Vol. 26, No. 2, 1963, p. 175. 